University of Nebraska - Lincoln

DigitalCommons@University of Nebraska - Lincoln

Faculty Publications: Department of

Entomology

Entomology, Department of

2006

\title{
Oil-Soluble Dyes for Marking Spodoptera frugiperda (Lepidoptera: Noctuidae)
}

\author{
Elis Christine Vilarinho \\ UNESP-Sa o Paulo State University \\ Odair Aparecido Fernandes \\ UNESP-Sa o Paulo State University, oafernandes@fcav.unesp.br \\ Celso Omoto \\ Fitopatologia e Zoologia Agrõ'cola \\ Thomas E. Hunt \\ University of Nebraska-Lincoln, thunt2@unl.edu
}

Follow this and additional works at: https://digitalcommons.unl.edu/entomologyfacpub

Part of the Entomology Commons

Vilarinho, Elis Christine; Fernandes, Odair Aparecido; Omoto, Celso; and Hunt, Thomas E., "Oil-Soluble Dyes for Marking Spodoptera frugiperda (Lepidoptera: Noctuidae)" (2006). Faculty Publications:

Department of Entomology. 296.

https://digitalcommons.unl.edu/entomologyfacpub/296

This Article is brought to you for free and open access by the Entomology, Department of at DigitalCommons@University of Nebraska - Lincoln. It has been accepted for inclusion in Faculty Publications: Department of Entomology by an authorized administrator of DigitalCommons@University of Nebraska - Lincoln. 


\title{
Oil-Soluble Dyes for Marking Spodoptera frugiperda (Lepidoptera: Noctuidae)
}

\author{
ELIS CRISTINE VILARINHO,${ }^{1}$ ODAIR APARECIDO FERNANDES, ${ }^{1}$ CELSO OMOTO ${ }^{2}$ \\ AND THOMAS E. HUNT ${ }^{3}$
}

\section{J. Econ. Entomol. 99(6): 2110-2115 (2006)}

\begin{abstract}
Although various biological aspects of Spodoptera frugiperda (J.E. Smith) (Lepidoptera: Noctuidae) have been examined, adult movement and dispersal of this insect pest is not well understood. Release-recapture techniques by using marked insects is a useful approach for dispersal studies; however, the marking technique should not significantly affect insect biology or behavior. Therefore, the effect of different concentrations of oil-soluble dyes (Solvent Blue 35 [C.I. 61554], Sudan Red 7B [C.I. 26050], Sudan Black B [26150], Sudan Orange G [C.I. 11920], and Sudan I 103624 [C.I. 12055]) on development, mortality, and fecundity of S. frugiperda was evaluated. Dyes were added to artificial diet used to feed larvae. Larval and pupal development and mortality, adult longevity, and female fecundity were evaluated. High concentrations (400 and $600 \mathrm{ppm}$ ) of all dyes led to longer larval and pupal stages. Adult life span and number of eggs were not affected by the dyes. Sudan Red 7B marked both adults and eggs very well. Solvent Blue 35 marked both adults and eggs, but the blue-marked eggs could not be distinguished from some bluish eggs laid by nonlabeled females. Adults and eggs were not adequately marked by the Sudan Black B, Sudan Orange G, and Sudan I 103624 (a yellow dye).
\end{abstract}

KEY WORDS release-recapture, insect dispersal, resistance management

Fall armyworm, Spodoptera frugiperda (J.E. Smith) (Lepidoptera: Noctuidae), is a major pest of corn, Zea mays L., in North, South, and Central America, and it is the primary target of Bt transgenic corn in Brazil. Larvae feed on the new leaves in corn (whorl) and can cause $15-34 \%$ yield reduction (Cruz 1995). In Brazil, losses caused by fall armyworm are estimated to be $\approx 400$ million dollars a year in corn alone (Cruz et al. 1999). Because this pest is also abundant on several other crops, numerous ecological studies have been carried out to develop better sampling and control strategies (Cruz 1995). However, because the fall armyworm is a polyphagous herbivore, an integrated pest management (IPM) program has been difficult to develop (Pencoe and Martin 1981).

Several biological aspects of the fall armyworm have already been studied (Cruz 1995); however, pre- and postmating movement and dispersal are not well understood. Understanding fall armyworm movement is very important for developing IPM programs, which includes resistant pest management (Caprio 1998). The use of refugia is one important tactic for resistant pest management. The primary goal for using refugia

\footnotetext{
${ }^{1}$ Departamento de Fitossanidade/FCAV,UNESP-São Paulo State University, 14884-900, Jaboticabal SP, Brazil.

${ }_{2}^{2}$ Departamento de Entomologia, Fitopatologia e Zoologia Agrícola, ESALQ/USP, 3418-900, Piracicaba, SP, Brazil.

${ }^{3}$ Corresponding author: Department of Entomology, University of Nebraska, Haskell Agricultural Laboratory, 57905866 Road, Concord, NE68728 (e-mail: thunt2@unl.edu).
}

is to reduce the adaptive value of resistant insects and degree of inheritance of resistant characteristics of the progeny by providing susceptible insects to mate with possible resistant insects (Gould 1998). For implementing refugia, information on insect movement and mating behavior is required.

Studies of insect movement in the field are often carried out using insect mark-recapture techniques that allow evaluation of dispersal, population dynamics, feeding behavior, trophic, and other ecological interactions (Southwood 1992). Marking should be environmentally safe, inexpensive, and easy to use (Hagler and Jackson 2001) and should not significantly affect the biology or behavior of the target organism (Hunt et al. 2000). A basic requisite of using mark-recapture technique is that marking be kept on the insect until its recapture and be easily identified (Southwood 1992). This is necessary to sort marked and nonmarked (wild) insects collected in the field.

Marking insects through incorporation of oil-soluble dyes in the diet has several advantages over other marking methods. Most oil-soluble dyes are cheap and require minimal handling. Another advantage is that such dyes are easy to identify in labeled insects and are not likely to be excreted by the insects (Hagler and Jackson 2001). Coleoptera, Lepidoptera, Diptera, Isoptera, and Hymenoptera have been successfully marked with dyes (Qureshi et al. 2004). Two currently available oil-soluble dyes, Solvent Blue 35 (C.I. 61554) and Sudan Red 7B (C.I. 26050), have been used to 
successfully mark Lepidoptera by adding them to added to insect diets (Ostlie et al. 1984, Hunt et al. 2000, Qureshi et al. 2004); however, dyes are not universally suitable across insect species, so each dye must be tested for each species under study (Hunt et al. 2000, Qureshi et al. 2004). Sudan Blue 670, a synonym of Solvent Blue 35, satisfactorily marked the European corn borer, Ostrinia nubilalis (Hübner) (Ostlie et al. 1984, Hunt et al. 2000) as did Sudan Red 7B (Hunt et al. 2000). The southwestern corn borer, Diatraea grandiosella Dyar, also was marked satisfactorily by Sudan Blue 670 and Sudan Red 7B (Qureshi et al. 2004).

Information on the movement and dispersal of fall armyworm is required for the development of effective IPM and resistance management programs, and identifying dyes that adequately mark these insects can be used in insect dispersal studies. The purpose of this project is to evaluate the effect of different oilsoluble dyes on S. frugiperda development, longevity, and fecundity.

\section{Materials and Methods}

The experiments were carried out in the Applied Ecology Laboratory, UNESP, São Paulo State University, Jaboticabal, SP, Brazil. Fall armyworms were taken from a mass rearing colony kept in the laboratory $\left(25 \pm 3^{\circ} \mathrm{C}, 70 \pm 10 \mathrm{RH}\right.$, and a photoperiod of 12:12 [L:D] h) by using a modified bean-based diet (Parra 1999). The diet was prepared and cut in small cubes $\left(4 \mathrm{~cm}^{3}\right)$. A single cube was placed in a $50-\mathrm{ml}$ plastic cup. First instars were individualized and placed in the plastic cups along with diet. The cups were then kept closed by using an acrylic lid. The insects were held in a climatic chamber $\left(25 \pm 2^{\circ} \mathrm{C}\right.$ and a photoperiod of 12:12 [L:D] h) until adult emergence.

Preparation of dye solutions was similar for all experiments. Oil-soluble dyes were purchased from Sigma-Aldrich Corporation (St. Louis, MO) and incorporated into artificial diet. The following dyes were tested: Solvent Blue 35 (C.I. 61554), Sudan Red 7B (C.I. 26050), Sudan Black B (C.I. 26150), Sudan Orange G (C.I. 11920), and Sudan I 103624 (C.I. 12055). Dye was incorporated into the diet following the procedures of Ostlie et al. (1984). The dye was diluted in corn oil ( $1 \mathrm{~g}$ of dye $/ 10 \mathrm{ml}$ of oil) and then incorporated into the diet to obtain the desired concentrations (e.g., $0.1 \mathrm{ml}$ of the dye solution was incorporated into 1 liter of diet for a final concentration of $100 \mathrm{ppm})$. The treatments were composed of a control (only diet), corn oil enriched diet (corn oil control), and oil-soluble-dye enriched diets.

Experiment 1: Evaluation of Blue (Solvent Blue 35), Red (Sudan Red 7B), and Black (Sudan Black B) Dyes at 400 and 600 ppm Concentrations. Forty firstinstars were individualized into plastic cups per treatment. There were 10 replications, each replication composed of four larvae. The treatments were composed of artificial diet enriched with corn oil ( 400 and $600 \mathrm{ppm}$ ), blue dye (400 and $600 \mathrm{ppm})$, red dye (400 and $600 \mathrm{ppm}$ ), black dye (400 and $600 \mathrm{ppm}$ ), and artificial diet without oil or dye (control). Each treatment was prepared separately.

Experiment 2: Evaluation of Blue (Solvent Blue 35) and Red (Sudan Red 7B) Dyes at 100, 250, and 400 ppm Concentrations. Fifty first instars were individualized per treatment. There were 10 replications, each replication composed of five larvae. The treatments were composed of different dyes added to artificial diet as follows: blue dye (100, 250, and $400 \mathrm{ppm})$, red dye $(100,250$, and $400 \mathrm{ppm})$, and control (no dye). The $400 \mathrm{ppm}$ of both blue and red dyes was included for further comparison with experiment 1 results.

Experiment 3: Evaluation of Red (Sudan Red 7B), Orange (Sudan Orange G), and Yellow (Sudan I 103624) Dyes at 250, 400, and $600 \mathrm{ppm}$ Concentrations. Sixty first instars were individualized per treatment. There were 10 replications, each replication composed of six larvae. Different dye colors were again added to artificial diet. The treatments follow: orange dye $(250,400$, and $600 \mathrm{ppm})$, yellow dye (250, 400 , and $600 \mathrm{ppm})$, red dye (250 and $400 \mathrm{ppm})$, and control (no dye).

During the larval and pupal stages, the following parameters were evaluated: larval mortality, larval period, mortality of prepupae, pupal mortality, and pupal period. The observations were carried out daily. For both the second and third experiments, longevity of adults also was evaluated. For such evaluation, newly emerged adults were individualized into polyvinyl chloride (PVC) cages $(20 \mathrm{~cm}$ in height $\times 10 \mathrm{~cm}$ in diameter) covered with voiale, in which they were kept until their death. In addition, newly emerged adults were separated by sex and separated into two groups. Concurrently, emerged males and females were paired and placed into PVC cages for egg production evaluation, and remaining adults were frozen $\left(-5^{\circ} \mathrm{C}\right)$ to confirm internal marking. For the egg production study, the male-female pairs from experiment 2 were placed in cages, one pair per cage. The cages were internally covered with white paper sheet to allow oviposition. Adults were fed with cotton pads soaked with a honey solution (5\%) kept on small plastic dishes $(1 \mathrm{~cm}$ in height by $3 \mathrm{~cm}$ in diameter). The dishes were left inside the cages and pads were changed daily. Inner papers with egg masses were removed daily (Hayes 1989). Each egg mass was observed under stereoscope to confirm marking and to count eggs. Eggs were counted using methodology proposed by Leuck and Perkins (1972) who suggested to count the eggs from the upper layer and multiply that number by the number of layers of the egg mass. Single eggs laid near the egg mass were observed and added to the total observed for the egg mass. The preoviposition period was recorded.

The frozen adults were dissected to observe marking of abdominal internal structures. The adults were laid on a petri dish for dissection under stereoscope. If necessary, water was used to keep insects moist. The abdomen was longitudinally cut and internal structures were observed. 
Table 1. Mean duration ( \pm SEM) of $S$. frugiperda larval and pupal stages in experiment 1

\begin{tabular}{llc}
\hline \hline \multirow{2}{*}{ Treatment } & \multicolumn{2}{c}{ Duration $(\mathrm{d})$} \\
\cline { 2 - 3 } & \multicolumn{1}{c}{ Larval } & Pupal \\
\hline Control (no dye) & $23.14 \pm 0.38 \mathrm{ab}$ & $8.08 \pm 0.35 \mathrm{bc}$ \\
Corn oil control, $400 \mathrm{ppm}$ & $22.56 \pm 0.66 \mathrm{~b}$ & $7.81 \pm 0.38 \mathrm{c}$ \\
Corn oil control, $600 \mathrm{ppm}$ & $24.37 \pm 1.00 \mathrm{ab}$ & $9.00 \pm 0.73 \mathrm{abc}$ \\
Blue, $400 \mathrm{ppm}$ & $26.60 \pm 0.80 \mathrm{ab}$ & $10.00 \pm 0.41 \mathrm{abc}$ \\
Red, $400 \mathrm{ppm}$ & $25.06 \pm 1.74 \mathrm{ab}$ & $9.19 \pm 0.84 \mathrm{abc}$ \\
Black, $400 \mathrm{ppm}$ & $26.01 \pm 0.55 \mathrm{ab}$ & $9.52 \pm 0.37 \mathrm{abc}$ \\
Blue, $600 \mathrm{ppm}$ & $26.54 \pm 0.84 \mathrm{a}$ & $9.94 \pm 0.47 \mathrm{ab}$ \\
Red, $600 \mathrm{ppm}$ & $26.45 \pm 0.71 \mathrm{a}$ & $9.62 \pm 0.35 \mathrm{abc}$ \\
Black, $600 \mathrm{ppm}$ & $26.23 \pm 0.55 \mathrm{a}$ & $10.66 \pm 0.40 \mathrm{a}$ \\
CV $(\%)$ & \multicolumn{1}{c}{8.85} & 13.89 \\
\hline
\end{tabular}

Statistical Analysis. The values of larval, pupal, and prepupal mortalities were transformed using arsine $\sqrt{ } \%+0.5$. Fecundity and preoviposition data were transformed using $\sqrt{\mathrm{x}+0.5}$, whereas longevity data were transformed using $\sqrt{ } \mathrm{x}$. These transformations were necessary to normalize the data and stabilize the variance. Analysis of variance (ANOVA) was performed, and means were separated by Tukey's test. Contrasts were performed using PROC GLM (SAS Institute 2001).

\section{Results and Discussion}

Larval Period and Mortality. In experiment 1, the addition of corn oil into the diet did not cause a significant effect on larval period (Table 1). There were no significant differences among treatments in larval period between the control, corn oil control (400 ppm), and larvae fed diet containing blue dye, red dye, or black dye at the $400 \mathrm{ppm}$ level (Table 1). There were no significant differences among treatments in larval period between the control, corn oil control (600 ppm), and larvae fed diet containing blue dye $(400$ and $600 \mathrm{ppm})$, red dye (400 and $600 \mathrm{ppm})$, or black dye ( 400 and $600 \mathrm{ppm}$ ), but larval periods for the blue, red, and black dye diets at the $600 \mathrm{ppm}$ level were significantly different $(F=4.10 ; \mathrm{df}=8,55 ; P=$ 0.0007 ) from the corn oil control at $400 \mathrm{ppm}$ (Table 1). Addition of dyes at higher concentration $(600 \mathrm{ppm})$ in the diet caused an increase of $\approx 4 \mathrm{~d}$ in the larval period compared with the larval period of insects fed on the corn oil control at $400 \mathrm{ppm}$. The black dye did not adequately mark the larvae, so it will not be discussed further.

When the larvae were fed on diets containing red dye at 100,250 , and $400 \mathrm{ppm}$ in experiment 2 , no significant differences were observed between the larval period of these insects and control insects (Table 2). The duration of the larval period for insects fed on diet containing blue dye at $100 \mathrm{ppm}$ was not significantly different from control insects (Table 2); however, the blue dye used at 250 and $400 \mathrm{ppm}$ significantly increased the larval period $(F=37.10 ; \mathrm{df}=$ $6,121 ; P=0.0001)$. Larvae of the control and blue dye added at $400 \mathrm{ppm}$ into the diet presented larval periods of 22.92 and $27.63 \mathrm{~d}$, respectively, indicating that the
Table 2. Mean duration \pm SEM of $S$. frugiperda larval and pupal stages and adult longevity in experiment 2

\begin{tabular}{lccr}
\hline \hline \multirow{2}{*}{ Treatment } & \multicolumn{3}{c}{ Duration (d) } \\
\cline { 2 - 4 } & Larval & Pupal & \multicolumn{1}{c}{$\begin{array}{c}\text { Adult } \\
\text { longevity }\end{array}$} \\
\hline Control (no dye) & $22.92 \pm 0.26 \mathrm{bc}$ & $9.60 \pm 0.22 \mathrm{~b}$ & $11.57 \pm 0.65 \mathrm{a}$ \\
Red, $100 \mathrm{ppm}$ & $21.87 \pm 0.40 \mathrm{c}$ & $9.92 \pm 0.20 \mathrm{ab}$ & $9.50 \pm 1.45 \mathrm{a}$ \\
Blue, $100 \mathrm{ppm}$ & $21.57 \pm 0.39 \mathrm{c}$ & $9.98 \pm 0.22 \mathrm{ab}$ & $12.00 \pm 1.64 \mathrm{a}$ \\
Red, $250 \mathrm{ppm}$ & $24.50 \pm 0.59 \mathrm{~b}$ & $9.55 \pm 0.20 \mathrm{~b}$ & $14.00 \pm 0.84 \mathrm{a}$ \\
Blue, $250 \mathrm{ppm}$ & $26.89 \pm 0.74 \mathrm{a}$ & $9.91 \pm 0.23 \mathrm{ab}$ & $10.50 \pm 1.55 \mathrm{a}$ \\
Red, $400 \mathrm{ppm}$ & $24.28 \pm 0.25 \mathrm{~b}$ & $9.67 \pm 0.16 \mathrm{ab}$ & $12.60 \pm 1.36 \mathrm{a}$ \\
Blue, $400 \mathrm{ppm}$ & $27.63 \pm 0.57 \mathrm{a}$ & $10.15 \pm 0.24 \mathrm{a}$ & $10.63 \pm 0.91 \mathrm{a}$ \\
CV $(\%)$ & 7.14 & 5.67 & 17.58 \\
\hline
\end{tabular}

${ }^{a}$ Original data, transformed for analysis by using $\sqrt{ } \mathrm{x}$ for longevity for ANOVA.

blue dye $(400 \mathrm{ppm})$ led to a $21.81 \%(\approx 5 \mathrm{~d})$ increase in the larval period.

In experiment 3 , there was no significant difference in larval period between the control and red dye at 250 ppm; however, there was a significant difference $(F=$ $75.28 ; \mathrm{df}=8,64 ; P=0.0001$ ) between larvae fed red dye at $400 \mathrm{ppm}(3.29 \pm 0.36 \mathrm{~d})$ and the control $(28.27 \pm 0.53 \mathrm{~d})$ (Table 3). Although few significant differences were observed in larval duration or larval and pupal mortality between the orange and yellow dye diets (Table 3 and 6), they did not adequately mark the larvae, so they are not discussed further.

In experiment 1 , the addition of corn oil into the diet did not cause a significant effect on larval $(F=0.80$; $\mathrm{df}=8,72 ; P=0.6028)$ or prepupal $(F=0.89 ; \mathrm{df}=8$, $72 ; P=0.5301$ ) mortality (Table 4 ). There were no significant differences in larval mortality between the control, corn oil controls (400 and $600 \mathrm{ppm}$ ), and the red dye diet at $600 \mathrm{ppm}$. The only significant difference in mortality among the red dye diets and the control or corn oil controls was between the control and the red dye diet at $400 \mathrm{ppm}$, where larval mortality for the red dye diet at $400 \mathrm{ppm}$ was significantly higher (Table 4). There were no significant differences in larval mortality between the corn oil controls ( 400 and $600 \mathrm{ppm}$ ) and the blue dye diet at $600 \mathrm{ppm}$, but larval mortality for the blue dye diet at $600 \mathrm{ppm}$ was significantly higher than the control (Table 4 ). There was

Table 3. Mean duration \pm SEM of $S$. frugiperda larval and pupal stages and adult longevity in experiment 3

\begin{tabular}{lccr}
\hline \hline \multirow{2}{*}{ Treatment } & \multicolumn{3}{c}{ Duration } \\
\cline { 2 - 4 } & Larval & Pupal & $\begin{array}{c}\text { Adult } \\
\text { longevity }\end{array}$ \\
\hline Control (no dye) & $26.21 \pm 0.30 \mathrm{ef}$ & $11.66 \pm 0.19 \mathrm{a}$ & $11.33 \pm 0.80 \mathrm{a}$ \\
Orange, $250 \mathrm{ppm}$ & $24.81 \pm 0.50 \mathrm{f}$ & $11.78 \pm 0.20 \mathrm{a}$ & $11.80 \pm 1.59 \mathrm{a}$ \\
Red, $250 \mathrm{ppm}$ & $27.34 \pm 0.34 \mathrm{de}$ & $11.47 \pm 0.17 \mathrm{a}$ & $12.53 \pm 0.53 \mathrm{a}$ \\
Yellow, $250 \mathrm{ppm}$ & $33.07 \pm 0.34 \mathrm{~b}$ & $11.37 \pm 0.25 \mathrm{a}$ & $13.86 \pm 1.25 \mathrm{a}$ \\
Orange, $400 \mathrm{ppm}$ & $24.78 \pm 0.43 \mathrm{f}$ & $11.29 \pm 0.25 \mathrm{a}$ & $13.67 \pm 1.23 \mathrm{a}$ \\
Red, $400 \mathrm{ppm}$ & $28.27 \pm 0.53 \mathrm{~d}$ & $11.64 \pm 0.21 \mathrm{a}$ & $10.82 \pm 0.52 \mathrm{a}$ \\
Yellow, $400 \mathrm{ppm}$ & $30.65 \pm 0.50 \mathrm{c}$ & $11.81 \pm 0.18 \mathrm{a}$ & $13.30 \pm 0.73 \mathrm{a}$ \\
Orange, $600 \mathrm{ppm}$ & $25.37 \pm 0.40 \mathrm{f}$ & $11.72 \pm 0.18 \mathrm{a}$ & $14.78 \pm 1.22 \mathrm{a}$ \\
Yellow, $600 \mathrm{ppm}$ & $39.50 \pm 0.65 \mathrm{a}$ & $11.13 \pm 0.31 \mathrm{a}$ & $13.00 \pm 0.91 \mathrm{a}$ \\
CV $(\%)$ & 4.79 & 5.31 & 10.69 \\
\hline
\end{tabular}

${ }^{a}$ Original data, transformed for analysis by using $\sqrt{ } \mathrm{x}$ for longevity for ANOVA. 
Table 4. Larval, prepupal, and pupal mortality \pm SEM of S. frugiperda in experiment 1

\begin{tabular}{llcc}
\hline \hline \multirow{2}{*}{ Treatment } & \multicolumn{3}{c}{ Mortality ${ }^{a, b}$} \\
\cline { 2 - 4 } & \multicolumn{1}{c}{ Larva } & Prepupa & Pupa \\
\hline Control (no dye) & $0.13 \pm 0.07 \mathrm{~cd}$ & $0.03 \pm 0.03 \mathrm{a}$ & $0.05 \pm 0.05 \mathrm{a}$ \\
Corn oil control & $0.18 \pm 0.05 \mathrm{bcd}$ & $0.00 \pm 0.00 \mathrm{a}$ & $0.05 \pm 0.05 \mathrm{a}$ \\
$\quad$ & & \\
$\quad 400 \mathrm{ppm}$ & & & \\
Corn oil control & $0.30 \pm 0.82 \mathrm{abc}$ & $0.00 \pm 0.00 \mathrm{a}$ & $0.10 \pm 0.06 \mathrm{a}$ \\
$\quad$ & & \\
$\quad 600 \mathrm{ppm}$ & $0.48 \pm 0.06 \mathrm{a}$ & $0.00 \pm 0.00 \mathrm{a}$ & $0.05 \pm 0.03 \mathrm{a}$ \\
Blue, $400 \mathrm{ppm}$ & $0.38 \pm 0.10 \mathrm{ab}$ & $0.03 \pm 0.03 \mathrm{a}$ & $0.03 \pm 0.03 \mathrm{a}$ \\
Red, $400 \mathrm{ppm}$ & $0.05 \pm 0.05 \mathrm{~d}$ & $0.00 \pm 0.00 \mathrm{a}$ & $0.05 \pm 0.03 \mathrm{a}$ \\
Black, $400 \mathrm{ppm}$ & $0.35 \pm 0.07 \mathrm{ab}$ & $0.00 \pm 0.00 \mathrm{a}$ & $0.08 \pm 0.04 \mathrm{a}$ \\
Blue, $600 \mathrm{ppm}$ & $0.30 \pm 0.05 \mathrm{abc}$ & $0.03 \pm 0.03 \mathrm{a}$ & $0.00 \pm 0.00 \mathrm{a}$ \\
Red, $600 \mathrm{ppm}$ & $0.05 \pm 0.03 \mathrm{~d}$ & $0.00 \pm 0.00 \mathrm{a}$ & $0.00 \pm 0.00 \mathrm{a}$ \\
Black, $600 \mathrm{ppm}$ & 29.23 & 17.87 & 35.85 \\
CV $(\%)$ & & & \\
\hline
\end{tabular}

${ }^{a}$ Original data, transformed for analysis by using arsine $\sqrt{\%}+0.5$

${ }^{b}$ Data are expressed as proportion.

no significant difference in larval mortality between the corn oil control at $600 \mathrm{ppm}$ and the blue dye diet at $400 \mathrm{ppm}$, but the blue dye diet at $400 \mathrm{ppm}$ was significantly higher than the control or corn oil control at $400 \mathrm{ppm}$ (Table 4 ).

There were no significant differences observed in experiment 2 for larval mortality between the control and diets containing red dye at 100, 250, or $400 \mathrm{ppm}$ (Table 5). There were no significant differences observed in larval mortality between the control and diets containing blue dye at 100 and $400 \mathrm{ppm}$, but the larval mortality was significantly higher $(F=3.75$; $\mathrm{df}=$ 9, 123; $P=0.0018$ ) for the blue dye diet at $250 \mathrm{ppm}$ than the control (Table 5).

In experiment 3 , there was no significant difference in larval mortality between control and red dye diet at 250 or 400 ppm (Table 6 ).

Of the two dyes that adequately marked that larvae, Solvent Blue 35 and Sudan Red 7B, both had some level of effect on larval development, although in most cases the effects were not significant, minimal, or inconsistent. The red dye diets had less effect than the blue dye diets. When a specific dye diet was observed to be significantly different than a respective control, it was not significantly different from one of the other controls (e.g., corn oil control or no oil control) or other dye treatments. This is similar to previous work where Sudan Blue 670 and Sudan Red 470 7B (a syn-

Table 5. Larval, prepupal, and pupal mortality \pm SEM of S. frugiperda in experiment 2

\begin{tabular}{lccc}
\hline \hline \multirow{2}{*}{ Treatment } & \multicolumn{3}{c}{ Mortality $^{a, b}$} \\
\cline { 2 - 4 } & Larva & Prepupa & Pupa \\
\hline Control (no dye) & $0.02 \pm 0.01 \mathrm{~b}$ & $0.00 \pm 0.00 \mathrm{a}$ & $0.01 \pm 0.01 \mathrm{a}$ \\
Red $100 \mathrm{ppm}$ & $0.00 \pm 0.00 \mathrm{~b}$ & $0.00 \pm 0.00 \mathrm{a}$ & $0.02 \pm 0.01 \mathrm{a}$ \\
Blue $100 \mathrm{ppm}$ & $0.02 \pm 0.01 \mathrm{~b}$ & $0.03 \pm 0.02 \mathrm{a}$ & $0.02 \pm 0.01 \mathrm{a}$ \\
Red $250 \mathrm{ppm}$ & $0.06 \pm 0.02 \mathrm{ab}$ & $0.06 \pm 0.03 \mathrm{a}$ & $0.01 \pm 0.01 \mathrm{a}$ \\
Blue $250 \mathrm{ppm}$ & $0.16 \pm 0.05 \mathrm{a}$ & $0.02 \pm 0.01 \mathrm{a}$ & $0.00 \pm 0.00 \mathrm{a}$ \\
Red $400 \mathrm{ppm}$ & $0.06 \pm 0.02 \mathrm{ab}$ & $0.07 \pm 0.03 \mathrm{a}$ & $0.01 \pm 0.01 \mathrm{a}$ \\
Blue $400 \mathrm{ppm}$ & $0.09 \pm 0.03 \mathrm{ab}$ & $0.03 \pm 0.02 \mathrm{a}$ & $0.00 \pm 0.00 \mathrm{a}$ \\
CV $(\%)$ & 34.76 & 29.27 & 18.82 \\
\hline
\end{tabular}

${ }^{a}$ Original data, transformed for analysis by using arsine $\sqrt{\%}+0.5$

${ }^{b}$ Data are expressed as proportion.
Table 6. Larval, prepupal, and pupal mortality \pm SEM of S. frugiperda in experiment 3

\begin{tabular}{lllr}
\hline \hline \multirow{2}{*}{ Treatment } & \multicolumn{3}{c}{ Mortality $a, b$} \\
\cline { 2 - 4 } & \multicolumn{1}{c}{ Larva } & \multicolumn{1}{c}{ Prepupa } & Pupa \\
\hline Control (no dye) & $0.05 \pm 0.03 \mathrm{c}$ & $0.02 \pm 0.02 \mathrm{~b}$ & $0.03 \pm 0.02 \mathrm{a}$ \\
Orange, $250 \mathrm{ppm}$ & $0.37 \pm 0.05 \mathrm{ab}$ & $0.08 \pm 0.03 \mathrm{ab}$ & $0.03 \pm 0.02 \mathrm{a}$ \\
Red, 250 ppm & $0.05 \pm 0.03 \mathrm{c}$ & $0.02 \pm 0.02 \mathrm{~b}$ & $0.02 \pm 0.02 \mathrm{a}$ \\
Yellow, $250 \mathrm{ppm}$ & $0.13 \pm 0.02 \mathrm{bc}$ & $0.03 \pm 0.02 \mathrm{ab}$ & $0.00 \pm 0.00 \mathrm{a}$ \\
Orange, $400 \mathrm{ppm}$ & $0.37 \pm 0.05 \mathrm{ab}$ & $0.03 \pm 0.02 \mathrm{ab}$ & $0.02 \pm 0.02 \mathrm{a}$ \\
Red, 400 ppm & $0.05 \pm 0.03 \mathrm{c}$ & $0.02 \pm 0.02 \mathrm{~b}$ & $0.02 \pm 0.02 \mathrm{a}$ \\
Yellow, 400 ppm & $0.22 \pm 0.06 \mathrm{bc}$ & $0.10 \pm 0.06 \mathrm{ab}$ & $0.03 \pm 0.02 \mathrm{a}$ \\
Orange, 600 ppm & $0.08 \pm 0.04 \mathrm{c}$ & $0.15 \pm 0.04 \mathrm{a}$ & $0.02 \pm 0.02 \mathrm{a}$ \\
Yellow, 600 ppm & $0.60 \pm 0.10 \mathrm{a}$ & $0.00 \pm 0.00 \mathrm{~b}$ & $0.00 \pm 0.00 \mathrm{a}$ \\
CV $(\%)$ & 29.44 & 30.80 & 25.92
\end{tabular}

${ }^{a}$ Original data, transformed for analysis by using arsine $\sqrt{\%}+0.5$.

${ }^{b}$ Data are expressed as proportion.

onym of Sudan Red 7B) dyes added to artificial diet also affected larval period of $O$. nubilalis (Ostlie et al. 1984, Hunt et al. 2000), so a reduction in the concentration of dyes from $600 \mathrm{ppm}$ was recommended to reduce negative effects (Ostlie et al. 1984). Female D. grandiosella larval consumed more and development was prolonged on a diet containing Sudan Red 7B (Qureshi et al. 2004), which was thought to be because they were more resource dependent and paid a higher metabolic price than did males, although these effects were considered minor. Inconsistent effect of dyed diets also has been observed, when another red dye (Calco Oil Red WP N-1700) increased the larval period of Helicoverpa zea (Boddie) in one study (Burton and Snow 1970) and had no effect in another study (Jones et al. 1975).

Pupal Period and Mortality. In experiment 1, the addition of corn oil into the diet did not cause a significant effect on pupal period (Table 1). There were no significant differences between the control, corn oil controls (400 and $600 \mathrm{ppm}$ ), or red and blue dye diets at $400 \mathrm{ppm}$, or red diet at $600 \mathrm{ppm}$ (Table 1). Pupal period was significantly lower for the corn oil control at $400 \mathrm{ppm}$ than the blue diet at $600 \mathrm{ppm}(F=$ $4.20 ; \mathrm{df}=8,53 ; P=0.0006)$, but there was no significant difference between the control diet and blue diet at $600 \mathrm{ppm}$.

In the experiment 2 , the pupal period of insects fed on diet with red dye in three concentrations (100, 250, and $400 \mathrm{ppm}$ ) did not significantly differ between each other or the control; however, larvae fed on a blue diet at $400 \mathrm{ppm}$ presented a significantly longer pupal period than the control (Table 2 ).

In the experiment 3 , there was no significant difference $(F=1.11$;f $=8,64 ; P=0.3679)$ in pupal period between the control and the red dye diets at 250 and 400 ppm (Table 3 ).

No significant differences were observed for prepupal or pupal mortality between the control, corn oil controls, or red or blue dye diets in experiments 1,2 , and 3 (Tables 4-6).

In general, the red dye had less effect on S. frugiperda larval and pupal periods than the blue dye. The elongation of either larval or pupal period may be related to metabolization of the dyes by the insects, 
Table 7. Preoviposition period and number of eggs per female $\pm \mathrm{SEM}$ in experiment 2

\begin{tabular}{lcc}
\hline \hline \multicolumn{1}{c}{ Treatment } & $\begin{array}{c}\text { Preoviposition }_{\text {period }^{a}} \\
\text { Control (no dye) }\end{array}$ & No. eggs $^{a}$ \\
Red, $100 \mathrm{ppm}$ & $3.80 \pm 0.33 \mathrm{a}$ & $947.90 \pm 150.27 \mathrm{ab}$ \\
Blue, $100 \mathrm{ppm}$ & $3.29 \pm 0.36 \mathrm{a}$ & $1601.86 \pm 222.07 \mathrm{a}$ \\
Red, $250 \mathrm{ppm}$ & $4.92 \pm 0.71 \mathrm{a}$ & $779.07 \pm 128.44 \mathrm{ab}$ \\
Blue, $250 \mathrm{ppm}$ & $5.83 \pm 1.94 \mathrm{a}$ & $922.50 \pm 223.09 \mathrm{ab}$ \\
Red, $400 \mathrm{ppm}$ & $3.00 \pm 0.58 \mathrm{a}$ & $460.33 \pm 214.83 \mathrm{ab}$ \\
Blue, $400 \mathrm{ppm}$ & $2.67 \pm 0.42 \mathrm{a}$ & $1657.83 \pm 238.46 \mathrm{a}$ \\
CV $(\%)$ & $6.50 \pm 1.94 \mathrm{a}$ & $502.60 \pm 382.92 \mathrm{~b}$ \\
\hline
\end{tabular}

${ }^{a}$ Original data, transformed for analysis using $\sqrt{x+0.5}$ for ANOVA.

where energy spent on the dye metabolism reduces the amount of energy available for development.

Adult Preoviposition Period, Fecundity, and Longevity. There were no significant differences in preoviposition period $(F=2.21 ; \mathrm{df}=6,42 ; P=0.0610)$ or fecundity $(F=0.08 ; \mathrm{df}=6,44 ; P=0.7753)$ between the control and the red and blue dye diets at any concentration (Table 7). In addition, there were no significant differences in adult longevity between the control and the red and blue dye diets at any concentration (Tables 2 and 3).

The dye was consumed and metabolized during the larval stage with sometimes a slight effect; however, after coping with the xenobionts in the larval and pupal stages, the dyes are retained by some tissues in the adult and do not affect adult longevity or fecundity. This is similar to work of Ostlie et al. (1984), where slight negative effects were observed in larval development when larvae fed on red (Sudan Red 470 7B) or blue (Sudan Blue $670 \mathrm{III}$ ) dye at $600 \mathrm{ppm}$, but negative effects were not observed for $O$. nubilalis adults from larvae fed on the same dye concentrations. Differences were observed, however, for $D$. grandiosella (Qureshi et al. 2004), where females lived longer when fed a diet containing Sudan Red 7B than a diet containing Sudan Blue 670.

One hundred percent of the adults from larvae fed on diet containing red dye at 100, 250,400, and $600 \mathrm{ppm}$ had internal structures of the abdomen red pigmented. The blue dye also adequately labeled adults at 250,400 , and $600 \mathrm{ppm}$ (100\% were labeled); however, at $100 \mathrm{ppm}$ the blue dye did not adequately label the adults. A color gradient for both red and blue dyes was observed in the internal structures of labeled adults. Insects fed on higher dye concentration presented darker colored internal structures in the abdomen. Similar variation also was observed for $O$. nubilalis adults labeled using different concentrations of blue and red dyes (Hunt et al. 2000).

Among the dyes tested, the red dye labeled $100 \%$ of both adults and eggs of $S$. frugiperda when dyes were added at 250, 400, and $600 \mathrm{ppm}$ to the diet. Egg labeling also has been observed with other dyes and insect species (e.g., Hendricks and Graham 1970, Wilkinson et al. 1972, Hunt et al. 2000, Faroni et al. 2002, Qureshi et al. 2004). Eggs were labeled by blue dye only at 400 and $600 \mathrm{ppm}$ concentrations. The eggs laid by insects fed diet without dyes were predominantly brownish or grayish. Eggs obtained from insects fed on blue dye were bluish or greenish. Such colors also were observed in S. frugiperda eggs laid by the control insects as well as by mass-reared insects. Thus, the use of blue dye is constrained in adult movement and behavior studies of S. frugiperda because eggs laid by labeled and wild (non labeled) insects cannot be easily differentiated. Neither adults nor eggs were adequately labeled using the black, orange, or yellow dye (Sudan Black B [C.I. 26150], Sudan Orange G [C.I. 11920], and Sudan I 103624[C.I. 12055], respectively).

In conclusion, the results indicate that adults and eggs of S. frugiperda can be efficiently labeled by red dye (Sudan Red 7B, C.I. 26050) at different concentrations, although a color gradient can be observed. However, 400 and $600 \mathrm{ppm}$ concentrations of the red dye ensure adequate labeling of the internal abdomen of adults and eggs. Thus, because the concentration of $400 \mathrm{ppm}$ of red dye allows adults and egg labeling and caused negligible negative effect on the insect's biology, we recommend it for labeling $S$. frugiperda. The use of blue dye (Solvent Blue 35, C.I. 61554) at 250 and $400 \mathrm{ppm}$ likewise adequately labeled $S$. frugiperda and caused negligible negative effects on the insect's biology, but it is suggested only for adult labeling.

The technique of labeling insects by using different colors allows simultaneous insect releases from different sites. In the current study, only the red dye marked both adults and eggs whereas the blue dyemarked adults solely. Adult movement and behavior studies by using release and recapture of marked adults could be carried out using the two oil-soluble dyes. Moreover, this technique is not costly or timeconsuming because dyes can be easily incorporated into the diet. Currently, studies using these dyes are underway to evaluate the dispersal of adult $S$. frugiperda in and around maize fields in Jaboticabal, Brazil.

\section{Acknowledgments}

We thank T. O. Tanan for laboratory work. This work was supported by IRAC-BR (Insecticide Resistance Action Committee-Brazil). This is Journal Series No. 15186 of the Nebraska Agricultural Research Division and Contribution No. 1233 of the Department of Entomology, University of Nebraska-Lincoln.

\section{References Cited}

Burton, R. L., and J. W. Snow. 1970. A marker dye the corn earworm. J. Econ. Entomol. 63: 1976-1977.

Caprio, M. A. 1998. Evaluating resistance management strategies for multiple toxins in the presence of external refuges. J. Econ. Entomol. 91: 1021-1031.

Cruz, I. 1995. A lagarta-do-cartucho na lagarta do milho. In Empresa Brasileira De Pesquisa Agropecuária. Centro Nacional de Pesquisa em Milho e Sorgo. Sete Lagoas, Embrapa, CNPMS, Circular Técnica, 21.

Cruz, I., M. de L. C. Figueiredo, and M. J. Matoso. 1999. Controle biológico de Spodoptera frugiperda utilizando o parasitóide de ovos Trichogramma. Sete Lagoas, Embrapa, CNPS, Circular Técnica, 30. 
Faroni, L.R.D., C.R.F. Oliveira, J. R. Gonçalves, A. L. Matioli, and J. C. Zanúncio. 2002. Efeito do corante Calco Oil Red n-1700 sobre o desenvolvimento de Rhyzopertha dominica F. (Coleoptera: Bostrichidae). Rev. Bras. Armazenamento 27: 3-7.

Gould, F. 1998. Sustainability of transgenic insecticidal cultivars: integrating pest and ecology. Annu. Rev. Entomol. 43: 701-726.

Hagler, J. R., and C. G. Jackson. 2001. Methods for marking insects: current techniques and future prospects. Annu. Rev. Entomol. 46: 511-543.

Hayes, J. L. 1989. Detection of single and multiple trace elements labels in individuals eggs on diet-reared $H$. virescens. Ann. Entomol. Soc. Am. 82: 340-345.

Hendricks, D. E., and H. M. Graham. 1970. Oil-soluble dye in larval diet for tagging moths, eggs, and spermatophores of tobacco budworms. J. Econ. Entomol. 63: 1019-1020.

Hunt, T. E., R. L. Hellmich, J. M. Dyer, L. H. Higley, and J. F. Witkowski. 2000. Oil-Soluble dyes for marking European corn borer (Lepidoptera: Crambidae). J. Entomol. Sci. 35: 338-341.

Jones, R. L., W. D. Perkins, and A. N. Sparks. 1975. Heliothis zea: effects of population density and a marker dye in the laboratory. J. Econ. Entomol. 68: 349-350.

Leuck, D. B., and W. D. Perkins. 1972. A method of estimating fall armyworm progeny reduction when evaluating control achieved host plant resistance. J. Econ. Entomol. 65: 482-483.
Ostlie, K. R., L. G. Higley, L. V. Kaster, and W. B. Showers. 1984. European corn borer (Lepidoptera: Pyralidae) development, larval survival and adult vigor on meridic diets containing marker dyes. J. Econ. Entomol. 77: 118-120.

Parra, J.R.P. 1999. Técnicas de criação de insetos para programas de controle biológico. ESALQ/FEALQ, Piracicaba, Brazil.

Pencoe, N. L., and P. M. Martin. 1981. Development and reproduction of fall armyworm on several will grasses. Environ. Entomol. 10: 999-1002.

Qureshi, J. A., L. L. Buschman, J. E. Throne, and S. B. Ramaswamy. 2004. Oil soluble dyes incorporated in meridic diet of Diatraea grandiosella (Lepidoptera: Crambidae) as markers for adult dispersal studies. J. Econ. Entomol. 97: 836-835.

SAS Institute. 2001. Stat users guide, release 8.0 ed. SAS Institute, Cary, NC.

Southwood, T.R.E. 1992. Ecological methods: with particular reference to the study of insect populations. Chapman \& Hall, London, United Kingdom.

Wilkinson, J. D., R. K. Morrison, and P. K. Peters. 1972. Effect of Calco red N-1700 dye incorporated into a semiartificial diet of the imported cabbageworm, corn earworm, and cabbage looper. J. Econ. Entomol. 65: 264-68.

Received 24 March 2006; accepted 25 July 2006. 